HoST - Journal of History of Science and Technology

Vol. 13, no. 1, June 2019, pp. 1-27

10.2478/host-2019-0001

\title{
Introduction. Pesticides: Past and Present
}

\author{
José Ramón Bertomeu-Sánchez \\ López Piñero Interuniversity Institute, University of València
}

bertomeu@uv.es

Chemical agents have been employed in pest control for centuries, but during the second half of the nineteenth century their use intensified considerably. The increasing international commerce of seeds and crops, the expansion of monoculture across the planet, and the new modes of circulation provided by the new motorized transports (trains, cars, modern ships) led to a global spread of new pests, which explains, at least in part, the intensification of the use of chemical pesticides in agriculture. At the turn of the twentieth century, the use of arsenic compounds, copper salts and nicotine extracts was already a common practice in many parts of the world. Moreover, these agents were part of the processes of specialization and intensification in agriculture, which introduced new forms of land ownership and mechanized production and also expanded the modes of irrigation, the use of agrochemicals such as synthetic fertilizers and herbicides, and plant breeding techniques. Since the end of the World War II, synthetic pesticides have been essential elements of the intensification of agriculture and the so-called

(C) 2019 José Ramón Bertomeu-Sánchez. This is an open access article licensed under the Creative Commons Attribution-NonCommercial-NoDerivs License (http://creativecommons.org/licenses/by-nc-nd/3.0/). 
"Green Revolution," historical processes that cannot be dissociated from the research funding dynamics promoted both by governments and by industry.

Modern methods of agricultural production created new interconnections between capital, labour, materials, transportation networks, food markets and expert knowledge. They also introduced new forms of slow and invisible violence against the bodies of farmworkers and consumers due to the spread of millions of tonnes of the new agrochemicals, whose damaging effects were not fully understood (or controlled) at the time. As with other pollutants, the advent of new pesticides ushered in a new, unequal distribution of human and environmental hazards. ${ }^{1}$ Due to the dramatic changes of the mid-twentieth century, the dominant narrative of the history of pesticides focuses on DDT and on the transformations after the World War II. One of the most powerful narratives was created by Robert van den Bosch (1922-1978), an outstanding Californian entomologist who was heavily involved in pest control during the 1950s and 1960s. Using many examples taken from his professional practice, van den Bosch exposed the vested interests behind the "pesticide treadmill," which had marginalized other forms of pest management. ${ }^{2}$ Studies on DDT in the United States focused mainly on environmental problems, particularly on the problems caused to fauna, as the disappearance of the eagles from the American landscape so eloquently demonstrates. ${ }^{3}$ The public controversy surrounding the works of Rachel Louise Carson (1907-1964) reinforced the dominant narrative around DDT and the United States; her book Silent Spring raised the alarm in the 1960s, and in time led to the ban on DDT by the US Environmental Protection Agency. ${ }^{4}$ The narrative represented a success story for American environmentalism but it has also been

\footnotetext{
${ }^{1}$ For general overviews see Frederick Rowe Davis, Banned: A History of Pesticides and the Science of Toxicology (New Haven, CT: Yale University Press, 2014); Graham A Matthews, A History of Pesticides (Boston: Cabi, 2018); Rob Nixon, Slow Violence and the Environmentalism of the Poor (Cambridge: Harvard University Press, 2011); Deborah Fitzgerald, Every Farm a Factory: The Industrial Ideal in American Agriculture (New haven: Yale University Press, 2010). On early uses of pesticides see James E. McWilliams, American Pests: The Losing War on Insects from Colonial Times to DDT(New York: Columbia University Press, 2008); Matthew Holmes, "Melancholy Consequences: Britain's Long Relationship with Agricultural Chemicals Since the Mid-Eighteenth Century," Environment and History 25, no. 1 (2019): 117-34; George M. Cook, “'Spray, Spray, Spray!': Insecticides and the Making of Applied Entomology in Canada, 1871-1914," Scientia Canadensis 22 (1998-1999): 7-50. On other forms of pest control, see Hannah Gay, "Before and after Silent Spring: From Chemical Pesticides to Biological Control and Integrated Pest Management--Britain, 1945-1980," Ambix 59, no. 2 (2012): 88-108.

2 Robert van den Bosch, The Pesticide Conspiracy (Berkeley: University of California Press, 1989).

3 Bill Berry, Banning DDT: How Citizen Activists in Wisconsin Led the Way (Madison: Wisconsin Historical Society Press, 2014); Charles F. Wurster, DDT Wars: Rescuing Our National Bird, Preventing Cancer, and Creating Environmental Defense Fund (New York: Oxford University Press, 2015).

${ }^{4}$ Rachel Carson, Silent Spring (Houghton: Riverside Press Cambridge, 1962). For an introduction to the relevant historical literature, see the following special issues celebrating 50 years of Silent Spring: Anthony S Travis, ed., "Silent Spring at 50: Earth, Water, and Air," Special issue, Ambix 59, no. 2 (2012) and Frederick R. Davis, ed., "Silent Spring after Fifty Years," Special issue, Endeavour 36, no.4 (2012).
} 
challenged by Carson's opponents. A large group of authors, including many climate change deniers, have attacked her legacy, blaming her (and other critics of the pesticide treadmill) for the terrible consequences of banning DDT, using dramatic images of famines and epidemic outbreaks in the Third World to advance their own agendas. The anti-Carson revisionists have exploited the case as evidence of the evils of regulation and its damaging effects on free markets. The persistent controversy sheds light on the complex mixture of politics, mass media, economic interests and technoscience that shapes the public debate on pesticides. ${ }^{5}$

The current issue of HoST revisits these dominant narratives and offers fresh perspectives by approaching pesticides from less frequently studied angles, chronologies, and geographies. Specifically, it focuses on the first half of the twentieth century - before the publication of Rachel Carson's Silent Spring, in 1962 - and on two countries, Spain and Norway, both of which are located in peripheral regions of Europe and are scarcely mentioned in the master narratives. In this volume, these two very different social and environmental contexts are put side by side and the practices at stake analysed in detail. By shifting the perspective on pesticides in terms of chemicals, protagonists, time and space, this issue aims to contribute to rewriting the current narratives on pesticides while at the same time broadening our understanding of how these chemicals became so irreversibly inscribed in contemporary societies.

The papers in this special issue explore different actors, contexts, products, risks and social and environmental conflicts. In the first paper, Anne Jorunn Frøyen studies the years between 1933 and 1953, when legislation regulating the use of pesticides against insects and weeds was established in Norway. By analysing how knowledge of the effects of pesticides circulated among Norwegian beekeepers and their networks, she suggests that the actors' positions and standings influenced the knowledge they put into circulation and the knowledge they suppressed. The second paper, by Ximo Guillem-Llobat, investigates the introduction of hydrogen cyanide in the region of Valencia during the first decades of the twentieth century. Focusing on the perceptions of the safety of workers and consumers, the author follows this chemical which was relevant not only in Spanish agriculture but also in warfare, poisoning crimes and urban hygiene. In the third paper, José Ramón Bertomeu-Sánchez explores similar connections by analysing the mass introduction of lead arsenate in Spanish agriculture during the early 1940s and its collateral consequences in terms of criminal murders, food poisoning accidents and toxic exposure of farmworkers and rural communities. He regards arsenical pesticides as sociotechnological products which played a pivotal role in the joint establishment of both chemical-based agriculture and the emerging Francoist regime in Spain during the 1940s. The fourth paper, by May-Brith Ohman Nielsen, which will be published in the next issue, investigates how the new synthetic pesticides were introduced and forced upon Scandinavian

\footnotetext{
${ }^{5}$ Naomi Oreskes and Eric Conway, Merchants of Doubt. How a Handful of Scientists Obscured the Truth on Issues from Tobacco Smoke to Global Warming (New York: Bloomsbury, 2010), pp. 210-240.
} 
gardeners between 1942 and 1953. She studies several gardeners' associations and their magazines in Norway, Denmark and Sweden in connection to the pesticide industry, and the expert communities and the regulatory agencies involved. In so doing, Ohman Nielsen tracks the circulation of information supporting the extensive use of pesticides, not only to professional gardeners, fruit farmers and park keepers, but also to amateur family gardeners and allotment gardeners, thus encouraging the acceptance of pesticides among regular Scandinavian citizens. ${ }^{6}$

Finally, in this introduction to the special issue, I review the recent historical scholarship with the aim of offering a general context for the four case-studies. The review covers issues discussed in recent historical studies and analyzed in the four papers at the due local contexts: the sociomaterial agency of pesticides other than DDT, their different uses and risks, the coproduction of the pesticide treadmill and different political regimes, the global circulation of pests and pesticides, the fragmentation and inefficiency of the regulations, the role of different expert communities and regulatory agencies, and the resistance of victims and activists. By crossing the borders of different academic lines, I call for a multifaceted approach to pesticides (in past and present) as both material and political entities. ${ }^{7}$

\section{Before and after DDT}

Pesticides are commonly regarded as substances used to control organisms such as insects, fungi, weeds, and microbes that destroy plants, particularly those for food production. They are also used for many other purposes, from public health campaigns against vector insects that cause devastating diseases such as malaria, typhus and dengue, to urban fumigation for hygienic purposes or home spraying to eliminate annoying bugs. Today, a huge number of substances are employed as pesticides. The earliest pesticides included mineral compounds and extracts of natural products such as tobacco, chrysanthemum flower, or derris root. During the second half of the nineteenth century, new products were introduced such as copper fungicides (the most famous being the Bordeaux mixture of copper sulphate and calcium hydroxide) and arsenic compounds (Paris Green and calcium and lead arsenate), which maintained their predominance until the first third of the twentieth century. ${ }^{8}$ In a popular book written at the end of the nineteenth century, a horticulturalist of the New York State Agricultural Experiment

\footnotetext{
${ }^{6}$ The paper of May-Brith Ohman Nielsen was meant to be included in this issue but unfortunately, due to unforeseen circumstances, the author was not able to submit her piece in time. It will be published in the next issue - see HoST 13, no. 2, December 2019. I would like to express my gratitude to professors Guillem and Ohman-Nielsen for their valuable comments on this introduction.

${ }^{7}$ I would like to thank all the contributors, including the journal editors and the anonymous referees, for their continued support to this project.

${ }^{8}$ James Whorton, Before Silent Spring: Pesticides and Public Health in Pre-DDT America (Princeton (NJ): Princeton University Press, 1974).
} 
Station named Ernest Londeman (1867-1896) summarized recent advances in the "application of liquids and powers to plants for the purpose of destroying insects and fungi." The book was prefaced by Beverly Thomas Galloway (1863-1938), chief of the division of vegetable pathology at the US Department of Agriculture, and author of pioneering models of knapsack sprayers. He described the "rapid advance" in pest control as "almost a revolution in certain lines of agriculture," but he affirmed that perhaps things "had gone forward too fast" and that some "important fundamental questions" had been overlooked. ' Many late nineteenthcentury entomologists harboured mixed feelings about the pesticide revolution, in part because it marginalized other methods of pest control. Research into biological techniques continued at many experimental stations and was successfully introduced in agriculture. The director of the US Bureau of Entomology, Charles V. Riley, championed these biological methods before his death in $1895 .{ }^{10}$ However, his successor, Leland O. Howard, favoured the new chemical methods and played a central role in their popularization all over the world, as shown in the examples included in this volume. ${ }^{11}$

In the early 1940s, just before the massive arrival of the new organic pesticides, a popular textbook summarized the properties of more than a hundred products classified according to their uses and modes of action. The most important group were insecticides, divided into stomach poisons (basically, the arsenic group) and contact insecticides (rotenone, hellebore, pyrethrum, nicotine, oils and the new DDT). The other large groups were fungicides, basically including sulphur and copper compounds, of which the Bordeaux mixture was the most important. Other chemicals mentioned were employed as repellents, weed killers or for rodent control. A full section was devoted to spray equipment: atomizers, dusters, compressed-air sprayers, bucket pumps, knapsack or wheelbarrow sprayers, and various apparatuses conceived for use in cars, tractors, and aeroplanes. Finally, a section on "new chemicals" summarized the new substances whose pesticidal virtues had been discovered in recent years, most of them synthesized organic substances. ${ }^{12}$

\footnotetext{
${ }^{9}$ Ernest Gustavus Lodeman, The Spraying of Plants: A Succinct Account of the History, Principles and Practice of the Application of Liquids and Powders to Plants, for the Purpose of Destroying Insects and Fungi (New York and London: Macmillan and co, 1896), 2.

${ }^{10}$ Paolo Palladino, Entomology, Ecology, and Agriculture: The Making of Scientific Careers in North America, 1885-1985 (Amsterdam, The Netherlands: Harwood Academic Publishers, 1996), 80-97; McWilliams, American Pests: The Losing War on Insects from Colonial Times to DDT, 82-110.

${ }^{11}$ L. O. Howard, A History of Applied Entomology: Somewhat Anecdotal (Washington: The Smithsonian Institution, 1930); James E. McWilliams, "The Horizon Opened up Very Greatly': Leland O. Howard and the Transition to Chemical Insecticides in the United States, 1894-1927," Agricultural History 82, no. 4 (2008): 468-95.

${ }^{12}$ James Albertine McClintock and Wayne B. Fisher, Spray Chemicals and Application Equipment: A Textbook and Handbook of the Insecticide-Fungicide Industry and of Application Equipment (LaGrange, Ind.: Chicago, Ill: Horticultural Press, 1945).
} 
Introduction. Pesticides: Past and Present

DDT was perhaps the most successful new chemical of all. It had been synthesized many decades before, but its pesticidal properties only came to be employed in the early 1940s thanks to the studies of Paul Müller at the Geigy laboratories in Switzerland. ${ }^{13}$ DDT was first used in military campaigns in Italy, against vector insects producing typhus and malaria. The Rockefeller Foundation promoted these campaigns and supported the introduction of DDT in both public health and agriculture in Latin America and Europe. ${ }^{14}$ In 1953, the World Health Organization (WHO) launched a large-scale malaria eradication programme in Africa, based on the use of DDT. The global circulation of DDT during the 1950s and 1960s was due to the work of transnational institutions and the geopolitical strategies of the Cold War along with the involvement of chemical industry, intensive monoculture farming, media outlets, foreign policy officials and the network of experts who championed its use in both public health and pest control. ${ }^{15}$

Thanks to these campaigns, DDT came to be represented as the triumph of modern technology over pests and disease. The philanthropic discourse, along with the urgency for food and health created by war, meant that the first toxicological studies indicating its noxious effects

13 Christian Simon, DDT: Kulturgeschichte einer chemischen Verbindung (Basel: Christoph Merian Verlag, 1999); Lukas Straumann, Nützliche Schädlinge: Angewandte Entomologie, Chemische Industrie und Landwirtschaftspolitik in Der Schweiz 1874-1952 (Zürich: Chronos, 2005); Walter M. Jarman and Karlheinz Ballschmiter, "From Coal to DDT: The History of the Development of the Pesticide DDT from Synthetic Dyes till Silent Spring," Endeavour 36, no. 4 (2012): 131-42.

14 Walter Palmieri, "Environmental Imperialism in Sardinia : Pesticides and Politics in the Struggle against Malaria," in Nature and History in Modern Italy, eds. Marco Armiero and Marcus Hall, 7086, Ohio University Press Series in Ecology and History (Athens: Ohio University Press, 2010); Deborah Fitzgerald, "Exporting American Agriculture: The Rockefeller Foundation in Mexico, 194353," Social Studies of Science 16, no. 3 (1986): 457-83; Marcos Cueto, Missionaries of Science: The Rockefeller Foundation and Latin America (Bloomington: Indiana University Press, 1994); Peter J. Brown, "Failure-as-Success: Multiple Meanings of Eradication in the Rockefeller Foundation Sardinia Project, 1946-1951," Parassitologia 40, no. 1-2 (1998): 117-30; A. Opinel and G. Gachelin, "The Rockefeller Foundation and the Prevention of Malaria in Corsica, 1923-1951: Support given to the French Parasitologist Emile Brumpt," Parassitologia 46, no. 3 (2004): 287-302; Darwin H. Stapleton, "A Lost Chapter in the Early History of DDT: The Development of Anti-Typhus Technologies by the Rockefeller Foundation's Louse Laboratory, 1942--1944," Technology and Culture 46 (2005): 513 40; Eric D. Carter, "God Bless General Perón': DDT and the Endgame of Malaria Eradication in Argentina in the 1940s," Journal of the History of Medicine and Allied Sciences 64, no. 1 (2008): 78122; James L. A. Webb Jr., "The First Large-Scale Use of Synthetic Insecticide for Malaria Control in Tropical Africa: Lessons from Liberia, 1945-1962," Journal of the History of Medicine and Allied Sciences 66 (2011): 347-76.

15 David Kinkela, DDT and the American Century: Global Health, Environmental Politics, and the Pesticide That Changed the World (Chapel Hill: University of North Carolina Press, 2011). Elena Conis, "Debating the Health Effects of DDT: Thomas Jukes, Charles Wurster, and the Fate of an Environmental Pollutant," Public Health Reports 125, no. 2 (2010): 337-42; Elena Conis, "Beyond Silent Spring: An Alternate History of DDT,” Distillations, Science History Institute, February 14, 2017, https://www.sciencehistory.org/distillations/beyond-silent-spring-an-alternate-history-of-ddt (accessed November 28, 2018). 
on mammals and other wildlife were ignored. Its positive image encouraged its use in urban sanitary campaigns and in households in the United States in the mid-twentieth century; it also prompted a technocratic discourse based on the dream of controlling nature (both pests and illnesses) by means of chemicals. The appeal of DDT favoured the embrace of other synthetic pesticides along with the marginalization of other forms of pest control and the silencing of critical voices and precautionary tales. ${ }^{16}$

And yet, the "love story" between humans and DDT was not as straightforward as the standard account might suggest. Many toxicological studies of DDT were carried out soon after its introduction in the 1940s, offering substantial experimental evidence of the chemical's potential danger to mammals. Not only experts were sceptical about the innocuous nature of the new pesticides; in fact, large amounts were invested in publicity campaigns to convince the public that DDT was safe and was suitable for use in fields, in homes or in hospitals. ${ }^{17}$ For decades, many farmers relied on alternative methods of pest control, either due to their proved efficiency, or for economic reasons. The growing evidence of insect resistance raised further doubts about the value of pesticides as new methods of integrated pest control gained momentum in the late 1960s. The mass use of DDT in public health also aroused strong criticism from those who supported other forms of dealing with epidemics and who advocated caution regarding crude insecticide-based eradication methods, stressing the complex interaction between chemicals, insects, humans and the environment. ${ }^{18}$

In spite of its critics, DDT and many other organic compounds were introduced during the 1940s and 1950s. Among the organochlorine groups, another important chemical was lindane, a hexachlorocyclohexane isomer, which was used in agriculture and personal hygiene (against lice). Like many other persistent organic pollutants, lindane was banned in many countries during the 2000s, but its long-term effects continue to pose an environmental problem in many areas. Another example is the herbicide 2,4-dichlorophenoxyacetic acid (usually called 2,4-D) was related to the dioxin group and to Agent Orange used in the Vietnam war. As in other cases related to toxic products, scientists initially disagreed regarding its health hazards, but in the 1980s it was finally classified as a possible carcinogen to humans. Further studies

\footnotetext{
${ }^{16}$ Michelle Mart, Pesticides, a Love Story: America's Enduring Embrace of Dangerous Chemicals (Lawrence, Kansas: University Press of Kansas, 2015).

${ }^{17}$ Elena Conis, "Debating the Health Effects of DDT: Thomas Jukes, Charles Wurster, and the Fate of an Environmental Pollutant," Public Health Reports 125, no. 2 (2010): 337-42; Conis, "Beyond Silent Spring: An Alternate History of DDT."

${ }^{18}$ Sabine Marie Clarke, "Rethinking the Post War Hegemony of DDT," in Environment, Health and History, eds. Virginia Berridge and Martin Gorsky, 133-53 (London: Palgrave Macmillan, 2012). For a more general discussion see Linda Lorraine Nash, Inescapable Ecologies: A History of Environment, Disease, and Knowledge (Berkeley: University of California Press, 2006).
} 
showed that, when released in rivers, it produced degradation products which are highly toxic to aquatic life. ${ }^{19}$

In contrast to organochlorine pesticides, which were regarded as persistent pollutants in bodies or the environment, organophosphate chemicals such as parathion were found to be rapidly hydrolysed and degraded, and so toxicologists concluded that they presented a lower risk of food poisoning or long-term contamination of rivers and soils. However, several studies in the 1950s and 1960s confirmed that they were very dangerous to farmworkers and rural communities because they caused cholinesterase inhibition, and thus affected the functioning of the neurological system. In fact, organophosphate chemicals were first studied by German scientists working for I.G. Farben as potential nerve agents for use in warfare; the results were the infamous chemicals called tabun and sarin, whose production started in Germany in the late 1930s, many years before organophosphates were employed in pest control. ${ }^{20}$ The association between pesticides and warfare is not limited to these cases, as several papers included in this volume note (in particular, Guillem's study of cyanide compounds). Further connections have been stressed by historians in terms of shared materials, discourses, institutions, and experts. Some industries developed both chemical weapons and pesticides, sometimes employing similar technologies, raw materials, and human teams. Many expressions used in pesticide advertising also bear striking similarities to military metaphors: "war against insects," "extermination," "menace," "invasion," and so on. ${ }^{21}$

The impact of pesticides on human health and the environment depends not only on their active ingredients but also on the equipment used in their application. In the early twentieth century, many methods for spraying were available, using manually operated pumps and barrels either transported by the farmers or mounted on horse-drawn carts. Various kinds of nozzles, tanks, dusters and sprayers were also produced in order to enable users to adjust the flow rate and the stream. ${ }^{22}$ The introduction of aerial spraying in the 1920s opened up new possibilities for treating large monoculture fields as well as for public health campaigns against

\footnotetext{
${ }^{19}$ Ronald Brickman and Sheila Jasanoff, Controlling Chemicals. The Politics of Regulation in Europe and the United States (Ithaca: Cornell University Press, 1985); Edwin A. Martini, Agent Orange: History, Science, and the Politics of Uncertainty, Culture, Politics, and the Cold War (Amherst: University of Massachusetts Press, 2012).

${ }^{20}$ Davis, Banned, 91-115; Edmund Russell, War and Nature: Fighting Humans and Insects with Chemicals from World War I to Silent Spring (Cambridge: Cambridge University Press, 2001), 87-88.

${ }^{21}$ Russell, War and Nature. On cyanide compounds see Adam M. Romero, "Commercializing Chemical Warfare: Citrus, Cyanide, and an Endless War," Agriculture and Human Values 33, no. 1 (2016): 3-26. See also Guillem's paper in this issue and May-Brith Ohman Nielsen, "Kverk krekene! Strategier for å selge liv og død til norske hageeiere 1945-1975," in A selge liv og død, ed. May-Brith Ohman Nielsen, 12-45 (Joensuu: University Press of Eastern Finland, 2014).

${ }^{22}$ Lodeman, The Spraying of Plants. See Matthews, A History of Pesticides, 28-61.
} 
vector insects, or for military operations which involved the deforestation of huge areas. ${ }^{23}$ Examples of the latter include the use of Agent Orange during the Vietnam war, which not only caused dramatic environmental damage but also had devastating effects on the health of both military troops and rural communities - effects that lasted for decades, and were never medically treated or compensated in any way. ${ }^{24}$ Another example is the aerial fumigation of coca fields in Colombia as part of the US war on drug traffic, in which poor rural communities were exposed to large amounts of sprayed glyphosate. The spraying affected not just the targeted illegal plants, but many legally grown crops and cattle. The environmental impact sparked strong public resistance, and the Colombian government stopped the aerial fumigations in the mid-2000s. However, new attempts to resume the spraying have been made in recent years. ${ }^{25}$

\section{Uses and risks}

As the papers included in this issue show, the use of pesticides in agriculture created many problems. The extent to which these problems were made visible depended on the nature of the products, the stakeholders, the domestic and international regulations, and the processes of pesticide production, transportation and usage. Three different groups of problems have been stressed in the literature: exposure to toxins among industrial workers, farmers and rural communities; residues in food and groundwater; and damage to wild fauna and the environment in general.

While the health problems caused by new products such as DDT could remain invisible for years, other pesticides had been well known as poisons since ancient times and their toxic burden could hardly be ignored. Arsenic compounds, for example, had been widely employed over centuries for criminal purposes. Nineteenth-century toxicologists developed many ways to detect them in corpses in order to be able to present reliable evidence in court. ${ }^{26}$ These methods, however, could not be applied in the chronic poisoning produced by the exposure

${ }^{23}$ David D. Vail, Chemical Lands: Pesticides, Aerial Spraying, and Health in North America's Grasslands since 1945 (Tuscaloosa, Alabama: University Alabama Press, 2018); Pete Daniel, Toxic Drift: Pesticides and Health in the Post--World War II South (Baton Rouge, Louisiana State University Press, 2005), 48-59.

${ }^{24}$ Martini, Agent Orange.

${ }^{25}$ Kristina Lyons, "Chemical Warfare in Colombia, Evidentiary Ecologies and Senti-Actuando Practices of Justice," Social Studies of Science 48, no. 3 (2018): 414-37. I would like to thank Juan Felipe Moreno for kindly providing me details on his ongoing research on this topic.

26 José Ramón Bertomeu-Sánchez, "Managing Uncertainty in the Academy and the Courtroom: Normal Arsenic and Nineteenth-Century Toxicology," Isis 104, no. 2 (2013): 197-225; José Ramón Bertomeu-Sánchez, "From Forensic Toxicology to Biological Chemistry: Normal Arsenic and the Hazards of Sensitivity during the Nineteenth Century," in "Living in a Toxic World, 1800-2000," eds. Ximo Guillem-Llobat and José Ramón Bertomeu-Sánchez, Special issue, Endeavour 40, no. 2 (June 2016): 82-92. 
to low doses of pesticides in agriculture; their clinical effects were less conspicuous than in acute poisoning crimes. In contrast to the vast amount of data gathered by judges during criminal trials, medical records on peasants' health were scarce, incomplete, or unavailable. The problem proved to be a persistent one: in 1990, a large group of WHO experts recognized that there was "a general lack of epidemiological data on the impact of pesticides on human health." The authors mentioned only a few evaluations of the long-term effects of pesticides in workers occupationally exposed to these chemicals, in rural populations situated in areas of intensive pesticide use or in food consumers affected by pesticide residues. ${ }^{27}$

The dramatic poisoning effects of cyanide compounds were already well known when they were first used in agriculture at the beginning of the twentieth century. Like arsenic, cyanide compounds were employed for criminal purposes and chemical warfare but, in contrast to arsenic and DDT, their main hazards were the potential for accidents during the preparation of the products and fumigation. Tracing these accidents, Guillem's article in this issue reviews how hydrogen cyanide fumigations were adopted in Valencia thanks to the appropriation of methods developed in California at the beginning of the twentieth century. He shows how the Spanish standards for occupational accidents were conceived to apply to physical injuries rather than to acute intoxications (as happened with cyanide compounds) and even less to chronic poisoning, which is related to pesticides based on arsenic, DDT, organophosphate compounds, and so on. Guillem also describes the training programmes for the safe use of cyanide which were even more intensive than other courses on arsenic pesticides for farmers, taught by agricultural engineers and mentioned in the other two papers. Other studies have shown that these courses could provide protection guidelines for the farmworkers at risk, but they also served to encourage intensive use of pesticides while marginalizing other forms of pest control and other alternatives to toxic exposures. The "safe-use approach" also tends to place the responsibility on the shoulders of the poisoned farmworkers who are blamed for their careless use of equipment and products. ${ }^{28}$

Occupational poisoning in agriculture was invisibilized for other reasons as well. While new tools such as cholinesterase testing were introduced in the 1950s to detect chronic poisoning, the issue was always regarded as a minor question affecting only a small group of farmworkers. The problem could not be dealt by adopting the dominant approach to the control of toxic hazards in workplaces during the twentieth century: the framework based on threshold limit values (TLVs), that is, the concentrations of chemicals that industrial hygienists regarded as safe for workers. Apart from their intrinsic problems (only a small number of chemicals

\footnotetext{
27 World Health Organization, Public Health Impact of Pesticide Used in Agriculture (Geneva: WHO, 1990), 7.

28 Douglas L. Murray, Cultivating Crisis: The Human Cost of Pesticides in Latin America (Austin: University of Texas Press, 1994), 118-32.
} 
were in fact investigated), TLVs proved to be irrelevant for open fields and agricultural environments. ${ }^{29}$

The example of cyanide confirms that the manufacture and transportation of a pesticide was a further source of hazard, sometimes neglected in public debates. Pesticide production involves risks for industrial workers and the communities living nearby due to everyday pollution or dramatic accidents. ${ }^{30}$ In fact, some of the worst accidents in the chemical industry were related to products connected in some way to pesticide manufacturing, transport or storage. In Italy, in July 1976, the ICMESA chemical plant in Seveso released a toxic cloud of dioxin which affected thousands of people. The chemical reactor at the plant synthesized trichlorophenol, an intermediate substance in the production of cosmetic disinfectants and also organochlorine herbicides. The accident became a symbol of the European environmentalist struggle and gave rise to the safety regulations known as the Seveso directives. ${ }^{31}$ The Basel Convention also recalls the chemical spill at the Sandoz agrochemical warehouse in November 1986, which resulted in massive air pollution, soil contamination and the discharge of tonnes of organophosphate insecticides and fungicides into the Rhine. ${ }^{32}$ The most infamous accident took place in Bhopal in a pesticide plant (owned by Union Carbide) in December 1984, when a leak of methyl isocyanate gas affected tens of thousands of people. The gas was an intermediate chemical in the production of the pesticide Sevin, a chemical belonging to the carbamate family and introduced as a pesticide in the late 1950s, which is still widely used in gardens, commercial agriculture and forestry pest control. The victims faced huge difficulties in obtaining medical

${ }^{29}$ The problems are reviewed in David Pimentel and Hugh Lehman, The Pesticide Question: Environment, Economics, and Ethics (New York: Chapman \& Hall, 1993). For an historical analysis see Linda Nash, "The Fruits of Ill-Health: Pesticides and Workers' Bodies in Post-World War II California," Osiris 19 (2004): 203-19; Nash, Inescapable Ecologies; Linda Nash, "Purity and Danger: Historical Reflections on the Regulation of Environmental Pollutants," Environmental History 13, no. 4 (2008): 651-58. On the problems of TVLs in general, see Scott Frickel and Paul Edwards, "Untangling Ignorance in Environmental Risk Assessment," in Powerless Science? Science and Politics in a Toxic World, eds. Soraya Boudia and Nathalie F. Jas, 215-33 (New York: Berghahn Books, 2014); Nancy Langston, Toxic Bodies: Hormone Disruptors and the Legacy of DES (New Haven: Yale University Press, 2010). For other additional causes see François Dedieu, Jean-Noel Jouzel, and Giovanni Prete, "Les bénéfices du doute: les usages politiques de la sous évaluation des intoxications professionnelles liées aux pesticides en France et en Californie," Dossiers de l'Environnement de l'INRA, no. 35 (2015): 77-88; Jean-Noël Jouzel and Giovanni Prete, "La normalisation des alertes sanitaires. Le traitement administratif des données sur l'exposition des agriculteurs aux pesticides," Droit et société 96, no. 2 (2017): 241-56.

${ }^{30}$ For an example of the regular pollution produced by pesticide industry, see Marta Pujadas Garriga, "La creació d'un passiu ambiental a Catalunya: Història de la planta química de Flix al riu Ebre (18972013)" (PhD diss., Universitat Autònoma de Barcelona, 2015).

${ }^{31}$ Laura Centemeri, "The Seveso Disaster Legacy," in Nature and History in Modern Italy, eds. Marco Armiero and Marcus Hall, 251-73 (Athens: Ohio University Press, 2010).

32 Walter Giger, "The Rhine Red, the Fish Dead-the 1986 Schweizerhalle Disaster, a Retrospect and Long-Term Impact Assessment," Environmental Science and Pollution Research International 16 (August 2009): 98-111. 
assistance, and in gaining compensation after the trials, since the national and international regulations favoured the interests of multinational corporations. ${ }^{33}$ Three more tragic accidents have been recorded in the Mexican pesticide industry during the last three decades, in the Anaversa industry in Córdoba (May 1991), the Teckhem warehouse in Salamanca (September 2000) and the Dragón factory in Izúcar de Matamoros (March 2010). In all three instances, dangerous pollutants were released into the air, soil and water, affecting workers and thousands of residents in the area. ${ }^{34}$

Poisoning accidents have also been produced by pesticide residues in food and have caused widespread social alarm. Perhaps the most famous case of mass arsenic poisoning took place in Manchester at the beginning of the twentieth century, when a consignment of arseniclaced beer caused a large number of neuropathological disorders. A special Royal Commission was created and its members wrote a long report, including guidelines for avoiding further cases, but these recommendations were never fully enforced. ${ }^{35}$ In other cases, the detection of arsenic in food or drinks was employed as part of commercial strategies related to the control of international food trade. When arsenic was detected in American apples in the 1920s, British producers launched a public debate and recommended the consumption of local fruit. Several expert commissions were set up and a threshold value was suggested for the safe amounts of arsenic in food. ${ }^{36}$ Another large case of poisoning involved wine shipped from Spain to France, which sparked another debate on the sources of arsenic poisoning and the safe limits to be allowed in food and drink. ${ }^{37}$ Ever since then, pesticide residues in food and groundwater have been among the most important sources of contention for activists concerned with the intensive use of pesticides. ${ }^{38}$

The effects of pesticides on the environment also raised concern, particularly the damage to wildlife, birds, and bees. The article by Frøyen in this issue confirms that these problems were

\footnotetext{
${ }^{33}$ Sheila Jasanoff, "Bhopal's Trials of Knowledge and Ignorance," Isis 98, no. 2 (2007): 344-50; Tomás Mac Sheoin and Frank Pearce, eds., "Bhopal and After. The Chemical Industry as Toxic Capitalism," Special issue, Social Justice 41, no. 1-2 (2014); Bridget Hanna, "Making Exposure In/Visible: Epidemiology, Legitimacy, and Authority after Bhopal," The Journal of Asian Studies 76, no. 2 (2017): 409-21.

${ }^{34}$ Lilia América and Marisa Albert Jacott, México tóxico. Emergencias químicas (México, DF: Universidad Nacional Autónoma de México, 2012), 155-204.

35 Jim Phillips and Michael French, "The Pure Beer Campaign and Arsenic Poisoning, 1896-1903," Rural History: Economy, Society, Culture 9 (1998): 195-209; Matthew Copping, "Death in the Beer Glass: The Manchester Arsenic-in-Beer Epidemic of 1900-1 and the Long-Term Poisoning of Beer," Journal of the Brewery History Society 132 (2009): 31-57.

${ }^{36}$ Whorton, Before Silent Spring, 134-57.

${ }^{37}$ Ignacio Suay-Matallana and Ximo Guillem-Llobat, "Poisoned Wine: Regulation, Chemical Analyses, and Spanish-French Trade in the 1930s," Ambix 65, no. 2 (2018): 1-23.

38 John Wargo, Our Children's Toxic Legacy: How Science and Law Fail to Protect Us from Pesticides (New Haven: Yale University Press, 1998).
} 
noted from the very beginning of the use of arsenical pesticides, particularly by beekeepers who feared that their business might be seriously affected. Focusing on early twentieth-century Norway, Frøyen offers fresh perspectives on the problem by describing how these issues were perceived and handled by different historical actors: agriculture engineers, beekeepers, policy-makers, journalists, and so on. The problems were compounded by the introduction of hundreds of new synthetic products after the World War II. Today, the damage to wildlife is undisputed. In the case of bees, a group of US scientists discovered in mid-2000s what they called the Colony Collapse Disorder (CCD), which reduced colonies by between 30 and 90 percent. Further evidence has also been obtained concerning the parallel declines in wild pollinators and pollinator-dependent plants. ${ }^{39}$ Not only bees but other insect populations as well are declining at such high rates that some entomologists fear that this may lead to the extinction of about 40 percent of the insect species over the next few decades, in what has been termed the "insect apocalypse." Paradoxically, pesticides - substances introduced to maximize crop production - have placed in great jeopardy the organisms that are needed for producing crops. ${ }^{40}$

\section{Coproduction and global circulation}

Like silk worms and cochineal insects, bees have been exploited for economic purposes since ancient times. Their image contrasts with that of other insects regarded as pests which have to be destroyed or at least controlled. Indeed, cultural perceptions of the relationship between insects and humans have played an important role in the development of pest control management. Particular bugs can generate pest alarms in some contexts, but are regarded as harmless or even beneficial in other places or historical moments. These perceptions change over time; they are also locally specific, and are sometimes embedded in more general cultural values related to gender, class or ethnicity. The social materiality of pesticides has also to be understood in these changing environmental and social contexts. Social perceptions of the risks posed by pests and pesticides can be substantially shaped by government campaigns, agriculture extension courses, or industry publicity. In fact, image advertising was particularly powerful in the introduction of new pesticides such as DDT. ${ }^{41}$ The mass media can also help

39 Douglas B. Sponsler et al., "Pesticides and Pollinators: A Socioecological Synthesis," Science of The
Total Environment 662 (2019): 1012-27.
40 Francisco Sánchez-Bayo and Kris A. G. Wyckhuys, "Worldwide Decline of the Entomofauna: A
Review of Its Drivers," Biological Conservation 232 (2019): 8-27.
41 David D. Vail, "Toxic Fables: The Advertising and Marketing of Agricultural Chemicals in the
Great Plains, 1945-1985," Endeavour 36, no. 4 (2012): 165-73; Rubia Pereira Gaissler, "A história do
ambiente, ciência e sociedade contada pelo DDT: uma análise de discurso e de conteúdo da mídia dos
Estados Unidos e do Brasil entre 1944 e 2014" (PhD diss., Universidade Estadual de Campinas, 2015). 
victims to make their claims, or can encourage activism against extreme pesticide usage. ${ }^{42}$ In other cases, newspapers, documentaries or horror movies (such as "Them") can stir up fear of bug invasions and stimulate public action in pest control, frequently in connection with broader social imaginaries. Extreme examples are popular books such as Bugs or People, in which Wheeler McMillen claimed that spraying was a powerful antidote to both hunger and communism. ${ }^{43}$

The changing interspecies relations between insects and humans are connected to shifting social and ecological conditions. For instance, new forms of agriculture (such as large-scale monoculture) created radically different environmental conditions by the early twentieth century in terms of the expansion of pests. ${ }^{44}$ These conditions also affected the methods of pest control. The "Green Revolution," which prompted the extensive use of chemicals in agriculture, began to develop during the golden years of twentieth-century capitalism. The result was a regime of crop production based on agronomic technoscience (new seeds, heavy machinery, extended irrigation, intensive use of chemical fertilizers and pesticides); it supported the interests of capital-intensive farms, export agriculture, and urban elites and rejected the demands of traditional people regarding food security and long-term ecological stability. At the same time, intensive pesticide use generated frequent ecological crises which in turn fuelled economic and social problems, including land concentration, farmer impoverishment and displacement of rural communities, in addition to the poisoning exposure discussed in other parts of this paper. ${ }^{45}$

In the last decades of the twentieth century, making the most of the opportunities offered by capitalist globalization, many pesticide industries moved to countries with less stringent regulations on occupational and environmental hazards, where products banned in other countries are still allowed and the costs of safety norms can be substantially reduced or even circumvented. ${ }^{46}$ However, pesticide use is far from being restricted to capitalist countries. The papers included in this volume comprise examples of the progress of pesticides under authoritarian regimes. Pest control campaigns during the 1930s in Nazi Germany or Fascist

\footnotetext{
${ }^{42}$ See for instance Jean-Noël Jouzel and Giovanni Prete, “Des journalistes qui font les victimes?" Etudes rurales 198, no. 2 (2016): 155-70.

${ }^{43}$ Kinkela, DDT and the American Century, 132-33.

${ }^{44}$ On this issue see Brett L. Walker, Toxic Archipelago: A History of Industrial Disease (London: University of Washington Press, 2010), 22-46; John F. M. Clark, Bugs and the Victorians (Yale University Press, 2009); Maril Hazlett, “Woman vs. Man vs. Bugs': Gender and Popular Ecology in Early Reactions to Silent Spring," Environmental History 9, no. 4 (2004): 701-29; E. D. Melillo, "Global Entomologies: Insects, Empires, and the 'Synthetic Age' in World History," Past \& Present 223, no. 1 (1 May 2014): 233-70.

${ }^{45}$ Murray, Cultivating Crisis, 96.

46 David Pimentel et al., "Environmental and Economic Costs of Pesticide Use," BioScience 42, no. 10 (1992): 750-60; Murray, Cultivating Crisis.
} 
Italy are further examples of agrarian policies in which agrochemicals and plant breeding played an important role in the attempts to impose autarky. ${ }^{47}$ The composition of the pesticide industry (comprising multinational corporations, local manufacture, state companies, etc.) is another important issue. For instance, after the 1950s, the most important producer of agrochemicals in Mexico was a state industry (Guanomex), and so the Mexican government was at the same time the regulator and the owner of the pesticide industry. ${ }^{48}$ In African countries such as Ghana, the combination of powerful multinational corporations and weak and changing governments has prompted public inaction in pesticide control, with serious consequences in water pollution, food contamination, and accumulation of toxic compounds in farmers' bodies, representing "a worst-case example of the problems of the use of pesticides in vegetable production." ${ }^{4}$

In the Soviet Union, many chemical weapons plants were reassigned to pesticide production in the 1960s. The scale of pesticide application was intensive and the public health consequences were so serious that an extraordinary amount of research was performed on the impact of pesticide use. The results were kept secret until the 1990s. When the information was released, its analysis showed that "during the period of very high pesticide use, one out of every ten people who worked with pesticides was seriously ill." The authors of the report affirmed that "tens of millions of inhabitants of the Soviet Union suffered pesticide overexposure for many years and inevitably were acutely or chronically poisoned." ${ }^{50}$ In contrast, in socialist China several circumstances favoured alternative methods of pest control in the 1960s: the small scale of the pesticide industry and the limited access to the international trade of chemicals; autarky policies aimed at achieving self-sufficiency in terms of pest control; and the emphasis on mass mobilization, both as a political goal during the Mao years and as a forced response to the material and social circumstances when agricultural labour was abundant and agrochemicals scarce. These features were politically mobilized during the visit of several US entomologists to China in the mid-1970s and influenced the writings of Robert van den Bosch, who praised the country's pioneering integrated pest control programmes. ${ }^{51}$

\footnotetext{
${ }^{47}$ Tiago Saraiva and M. Norton Wise, "Autarky/Autarchy: Genetics, Food Production, and the Building of Fascism," Historical Studies in the Natural Sciences 40, no. 4 (2010): 419-28.

48 Sergio Fernández Bravo, "Adopción y producción estatal de DDT en México" (Master's thesis, Universitat de València, 2018); América and Jacott, México tóxico. Emergencias químicas.

49 William John Ntow, The Use and Fate of Pesticides in Vegetable-Based Agroecosystems in Ghana (London: CRC Press, 2008), 105. See also Megan Sheahan, Christopher B. Barrett, and Casey Goldvale, "Human Health and Pesticide Use in Sub-Saharan Africa," Agricultural Economics 48, no. 1 (2017): 27-41.

${ }^{50}$ Lev A. Fedorov and Alexey V. Yablokov, Pesticides: The Chemical Weapon That Kills Life (the USSR's Tragic Experience) (Sofia: Pensoft, 2004), 87-88.

51 Sigrid Schmalzer, "Insect Control in Socialist China and the Corporate United States: The Act of Comparison, the Tendency to Forget, and the Construction of Difference in 1970s U.S.--Chinese Scientific Exchange," Isis 104, no. 2 (2013): 303-29.
} 
The language of coproduction is frequently used to talk about pest control management and political regimes. The papers included in this volume are no exception. Though they focus on local cases, the authors highlight many transnational factors related to the pesticide industry, agrarian technologies, crop production and expert exchanges. While control campaigns are organized at local and national levels, pests are basically transnational. Many outbreaks have been accidentally caused by travel, international trade or war - sometimes with dramatic consequences like famine or epidemics in distant countries. Pesticides also disregard political boundaries. They drift through the air, settle in water and soils, and enter the bodies of animals and humans living in regions far from their sites of production and use. Persistent organic pollutants and their degradation products can be detected, for instance, in the bodies of Inuit communities who have never used agrochemicals. ${ }^{52}$ Moreover, pesticides are transported by the international trade of crops, producing the so-called "circle of poison": for instance, organochlorine pesticides such as DDT, whose use has been banned in developed nations, were sold to countries with less strict regulations, and returned to the First World by means of food imports thanks to the expansion of global trade..$^{53}$ Again, the effects are multipolar and complex. When consumers in rich countries grew alarmed, new pesticides were introduced in Third World agriculture - agents that produced fewer residues in food but were more dangerous for farmworkers and local communities..$^{54}$

\section{Fragmented regulations}

The transnational character of pests and pesticides was one of the reasons for the first attempts to introduce international regulation. Changing social perceptions also played their role in the emergence of early national regulations in the pesticide industry. Late nineteenth-century pest alarms called for control measures, and encouraged the use of pesticides. Some of the first laws at the national level were designed to prevent adulteration and fraud in the growing pesticide market. The US Federal Insecticide Act was passed in 1910 and was reformulated in 1947 with the approval of the new Insecticide, Fungicide and Rodenticide Act. Similar legislation was passed in France and Spain during the early 1940s, and in the Scandinavian countries in the early 1950s. These regulations ushered in the registration of pesticides at

\footnotetext{
52 Bruce Elliott Johansen, The Dirty Dozen: Toxic Chemicals and the Earth's Future (Greenwood Publishing Group, 2003), 47-74.

53 David Weir and Mark Schapiro, Circle of Poison: Pesticides and People in a Hungry World (San Francisco, CA: Food First Books, 1981); Stuart Harrad, Persistent Organic Pollutants (London: Wiley, 2010), 150-62.

${ }^{54}$ Angus Wright, "Rethinking the Circle of Poison: The Politics of Pesticide Poisoning among Mexican Farm Workers," Latin American Perspectives 13, no. 4 (1986): 26-59.
} 
national level. ${ }^{55}$ The other area of regulation was the residues in food. The pioneering work of Harvey W. Willey in the United States on food quality, and the poisoning scares with drinks and fruit during the 1920s mentioned above, paved the way for the Food, Drug and Cosmetic Act (1938), which imposed limits on the amounts of pesticide residues in food. Finally, in the 1970s new regulations were passed in order to meet the demands of environmental groups, which led to the banning of several products. ${ }^{56}$

The capacity of governments to regulate the hazards of the production and use of hazardous chemicals was limited, and the effects of the new regulations difficult to assess. While arsenic residues were limited in crops, arsenical herbicides (such as cacodylic acid) were used extensively, from golf courses to cotton fields. They were also widely used in the production of wood preservatives. ${ }^{57}$ The banning of organochlorine chemicals such as DDT in the 1970s provided commercial advantages for producers of organophosphate and carbamate pesticides, whose use soared during the following decades, but it brought in new kinds of risks for industrial and agriculture workers as well as for consumers, especially children. The growing number of active substances, the variety of uses, the range of risks and the growth of international trade in the second half of the twentieth century posed real challenges for regulators at the international level.

One of the first international actions was related to the labelling of pesticides. As early as 1951, the World Health Assembly passed a resolution on the dangers for workers using pesticides and noted the great variation in the regulations in force in different countries. The expert reports produced in those years alerted that the dangers affected not only the farmers using these products but also the workers in industries that produced dangerous pesticides as well as the surrounding communities. ${ }^{58}$ The WHO and the Food and Agriculture Organization (FAO) published several joint reports on these issues during the 1950s. During the 1960s and 1970s, two issues prompted international regulation: pesticide residues in crops, particularly those imported from Third World countries, and synthetic organic pesticides, which had become permanent pollutants moving all over the world.

The issue of residues was discussed by the Codex Alimentarius Commission, a joint institution created by the FAO and the WHO in 1963 to impose a set of internationally accepted food

\footnotetext{
${ }^{55}$ Nathalie Jas, "Public Health and Pesticide Regulation in France before and after Silent Spring," History and Technology 23, no. 4 (2007): 369-88. See paper by Bertomeu-Sánchez in this volume.

${ }^{56}$ McWilliams, American Pests, 137-56; Davis, Banned.

${ }^{57}$ Vladimir Bencko and Florence Yan Li Foong, "The History of Arsenical Pesticides and Health Risks Related to the Use of Agent Blue," Annals of Agricultural and Environmental Medicine 24, no. 2 (12 June 2017): 312-16.

${ }^{58}$ Rune Lönngren, International Approaches to Chemicals Control: A Historical Overview (Stockholm: Kemi, 1992), 59-66.
} 
standards. With experts from both institutions, a committee on pesticide residues was set up in the mid-1960s to deal with the study of acceptable levels in food to be incorporated into the Codex and implemented in national regulations. The role of the Codex changed substantially when the World Trade Organization (WTO) decided to adopt its standards in the mid-1990s. Policy makers used the epistemic authority of the Codex standards to harmonize consumer and environmental hazards in the midst of the expansion of the international food trade. But the main goal was not so much the protection of public or occupational health as economic efficiency (as it was conceived by WTO officials). ${ }^{59}$

Growing attention to environmental issues culminated in the creation of the UN Environment Programme in the 1970s. An agreement of three UN bodies (UNEP, ILO and WHO) created the International Programme on Chemical Safety at the end of the decade. ${ }^{60}$ The Basel (1989) and Rotterdam (1998) conventions introduced further regulations concerning the transnational trading of chemical pollutants. The main result concerning pesticides in the ensuing years was the Stockholm Convention on Persistent Organic Pollutants (POPs), which was adopted in 2001 and came into force as a global treaty in 2004. Most of the "dirty dozen" POPs included in the treaty were pesticides (DDT, aldrin, chlordane, heptachlor dieldrin, endrin, mirex, and toxaphene) with the aim of ceasing their production, use and trade. Other pesticides (for instance, hexachlorocyclohexane) were not included in the list, after extensive negotiations with reluctant governments. As for DDT, its use was accepted for disease vector control, particularly against malaria, and an expert committee was created to explore alternative methods. The committee held its seventh meeting in Geneva in November 2018. Another expert group was created to study new substances to be included in the list. The molecule-by-molecule approach involved the assessment of the persistence, bioaccumulation, environmental transport and adverse effects of each product. A list of 16 new chemicals were added during the 2010s, including high-usage pesticides such as isomers of hexachlorocyclohexane (lindane), chlordecone, endosulfan and pentachlorophenol. ${ }^{61}$

The European Community's (EC) directives on pesticide use took shape during the late 1970s, a period which coincided with several of the key developments associated with the FAO's pesticide programmes and the Organisation for Economic Co-operation and Development's (OECD) chemical testing programmes. The sixth amendment, which was similar to the US Toxic Substances Control Act, established an inventory of existing chemicals and required

\footnotetext{
59 David E. Winickoff and Douglas M. Bushey, "Science and Power in Global Food Regulation: The Rise of the Codex Alimentarius," Science, Technology \& Human Values 35, no. 3 (2010): 356-81.

${ }^{60}$ Lönngren, International Approaches to Chemicals Control, 254-83.

${ }^{61}$ Miquel Porta and Ernest Zumeta, "Implementing the Stockholm Treaty on Persistent Organic Pollutants," Occup Environ Med 59, no. 10 (2002): 651-52; Harrad, Persistent Organic Pollutants; Stockholm Convention Secretariat, The New 16 POPs (Geneva: UNE, 2017). See http://chm.pops.int/ (accessed November 28, 2018).
} 
a risk assessment for new chemicals prior to their being placed on the market. ${ }^{62}$ The new 1991 directive (91/414/EEC) introduced a dual authorization system: active substances were authorized at the level of the EC, while pesticide products were authorized at the national level. New attempts at harmonization were introduced when the European Union (EU) Regulation (1107/2009) came into force. However, these attempts faced a series of obstacles: the striking differences in pesticide use among European countries, the restrictions on the enforcement of EU regulations at national level, and the limited availability of alternatives to toxic pesticides in the national markets. ${ }^{63} \mathrm{~A}$ recent analysis of water samples in a number of European rivers and canals confirmed the presence of a hundred different pesticides, one-fifth of which have been banned in the EU for years. ${ }^{64}$

This brief review bears witness to the variety of the agencies regulating pesticides at national and international levels. This disparate array of legal structures, administrative procedures, treaties, information systems and convention standards has been dubbed the "molecular bureaucracy." Moreover, its components have changed over time, producing chaotic and inefficient results. Reviewing national and international regulations on toxic products over the last two centuries, Soraya Boudia and Nathalie Jas have attempted to organize them around different "modes of governance of risks": that is, ways in which "scientists, experts, public authorities, industry and activists think, conceive and manage the hazards of poisons," including pesticides. They claim that three modes of governance (by regulations, by risks and by adaptation) have appeared during the twentieth century. Rather than being replaced by each other, these modes have coexisted and produced hybrid situations in which very different conceptions and norms are at work, frequently opening up new opportunities to polluters seeking to escape regulation. ${ }^{66}$

The assorted and fragmentary nature of the regulations concerning pesticides in occupational health, food quality or the environment is one of the main constraints on ensuring their effectiveness. This fragmentation also serves to conceal the political and economic interests pushing these regulations; in many cases, the main purpose behind regulation was to safeguard

${ }^{62}$ Robert Boardman, Pesticides in World Agriculture: The Politics of International Regulation (Houndmills, Basingstoke, Hampshire: Palgrave Macmillan, 1986); Lönngren, International Approaches to Chemicals Control, 349-60.

${ }^{63}$ See for instance Ewa Matyjaszczyk and Joanna Sobczak, "Common EU Registration Rules and Their Effects on the Availability of Diverse Plant Protection Products: A Case Study from Oilseed Rape and Potato in 5 Member States," Crop Protection 100 (2017): 73-76.

${ }^{64}$ Jorge Casado et al., "Screening of Pesticides and Veterinary Drugs in Small Streams in the European Union by Liquid Chromatography High Resolution Mass Spectrometry," Science of the Total Environment 670 (2019): 1204-25.

65 Evan Hepler-Smith, "Molecular Bureaucracy: Toxicological Information and Environmental Protection," Environmental History, 24 (forthcoming).

${ }^{66}$ Soraya Boudia and Nathalie Jas, Gouverner un monde toxique (Paris: Quae, 2019). 
global crop trading, not to protect workers, consumers or the environment. ${ }^{67}$ Inspired by economic agencies or think tanks committed to capitalist dogmas, the regulations have sometimes reinforced inequalities between different stakeholders: polluters, experts, victims, policy-makers and activists. These inequalities are related not only to economic and political power, but also to access to decision-making, the regulating agencies and the mass media. It also involves different agency in the production of knowledge and ignorance on the hazards of pesticides. ${ }^{68}$ The recent decision of the European authorities concerning the herbicide glyphosate seems to be another example for future historians. The sudden changes of opinion of the decision-makers, along with the disregard for public debate and the strength of the lobbying by corporative powers, seems to confirm the views of van den Bosch regarding the "pesticide conspiracy," at least in terms of extreme imbalances between concerns for health and economic profit when dealing with pesticide regulation. Similar scandals have been reported in the first years of the Trump administration concerning the US Department of Agriculture (USDA) and the pesticides. ${ }^{69}$

\section{Experts and agencies}

The role of expert and advisory agencies is one of hottest topics in the studies on pesticides. As in other studies on experts, historians have noted the problems of selection, authority, trustworthiness, capture, and even corruption. Van den Bosch, himself a leading member of the expert community, claimed that specialists were corrupted by the government agencies and the chemical industry - that is, by the public and private institutions prompting the use of pesticides as the only method for pest control. He stated that "entomologists and other pest-control specialists were sucked into the vortex" of the pesticide treadmill, so for "an entire generation of researchers and teachers came to equate pest management with chemical control." 70

According to van den Bosch, experts following these trends were offered well-paid positions in academia and industry as well as access to laboratory resources and experimental farms, in

\footnotetext{
${ }^{67}$ Nathalie Jas, "Gouverner les substances chimiques dangereuses dans les espaces internationaux," in Le Gouvernement des technosciences: gouverner le progrès et ses dégâts depuis 1945, ed. Dominique Pestre, Collection Recherches, 31-65 (Paris: La Découverte, 2014).

${ }^{68}$ Susanna Rankin Bohme, "Pesticide Regulation, Citizen Action, and Toxic Trade: The Role of the Nation-State in the Transnational History of DBCP," in Dangerous Trade: Histories of Industrial Hazard across a Globalizing World, eds. Christopher Sellers and Joseph Melling, 168-80 (Philadelphia: Temple University Press, 2012). See also Brickman and Jasanoff, Controlling Chemicals; Soraya Boudia and Emmanuel Henry, La mondialisation des risques: une histoire politique et transnationale des risques sanitaires et environnementaux (Rennes: PUR, 2015).

${ }^{69}$ Union of Concerned Scientists, Betrayal at the USDA. How the Trump Administration Is Sidelining Science and Favoring Industry over Farmers and the Public (Cambridge, MA: UCS, 2018).

${ }^{70}$ Bosch, The Pesticide Conspiracy, 21.
} 
which they could develop their research programmes. This picture of experts "corrupted" by vested interest has been revised by subsequent historical studies. In his pioneering work on US economic entomologists, John Perkins explored perspectives other than the "corruption thesis" in search of more structural and invisible issues. Perkins discussed how the "socioeconomic organization of American farming" involved certain requirements of any successful pest control technology, thus favouring the use of pesticides. ${ }^{71} \mathrm{~A}$ call for a more nuanced analysis was also made by Thomas R. Dunlap in his pioneering historical study on DDT in the United States. Dunlap concluded that the victory of DDT over other forms of pest control was the result of many disparate issues: the social and economic situation of American farmers, the forms of regulation of toxic risks, the support for scientific research into agricultural problems, and the private profits to be made from chemical insecticides. In this multifaceted context, Dunlap affirmed that economic entomologists "came to favour chemicals" because they offered a means of insect control that, "because it gave dramatic, quick results, helped establish the value of the profession to the farmer." ${ }^{2}$

In a similar vein, but relying on a comparative analysis between the United States and Canada, Paolo Palladino dismissed the idea that entomologists were "the victims of a terrible, corporate conspiracy." On the contrary, he regarded them as "active participants in the evolution of the insecticide crisis" because "not only did they exploit existing institutional formations to advance their goals," "they also helped to shape them" in ways that marginalized other forms of pest control. While accepting the role of the chemical industry in encouraging the pesticide treadmill, Palladino noted that "the success of insecticides also rested on farmers' and entomologists' shared beliefs in technological progress and the control of nature." How these social perceptions were constructed and became dominant in certain groups in particular temporal and spatial contexts is thus an interesting topic for research. ${ }^{73}$

The papers included in this volume offer evidence of other expert communities involved in this process in Europe. In the case of the two papers focusing on the Iberian Peninsula, the protagonists are the agricultural engineers involved in pest control campaigns, and how their interests were intertwined with those of other historical actors such as industry, governments, and political groups. The two papers dealing with Scandinavia include valuable information on the attitudes and responses towards pesticides in different expert communities. The Norwegian beekeepers studied by Frøyen were able to collect evidence on the damage caused to bees, but their results were marginalized by agricultural experts and their concerns were ignored by those

\footnotetext{
${ }^{71}$ John H. Perkins, Insects, Experts, and the Insecticide Crisis: The Quest for New Pest Management Strategies (New York: Plenum Press, 1982).

72 Thomas R. Dunlap, DDT: Scientists, Citizens, and Public Policy (Princeton: University Press, 1981), 241.

73 Palladino, Entomology, Ecology, and Agriculture. Quoted on pp. 4-5 and 180-181.
} 
responsible for decision-making. Ohman Nielsen shows how these processes played out in the extensive arena of family gardening by analysing gardening associations and their membership magazines. Pesticide experts, gardening experts and industry instructed gardeners on the matters of pesticides. Her study shows that amateur gardeners had their own perceptions and their own agency, but most of them followed the experts' advice and often remained faithful to specific pesticide practices, even long after these products had been banned from the market. ${ }^{74}$

Recent studies on experts offer further possibilities to explore these connections: experts captured by industries, revolving doors between regulators and stakeholders, forms of coproduction of political and scientific realms, experts turned into activists or the other way around, or experts unaware of more invisible social structures promoting political inaction, or undone science, or both. These studies also show a broad spectrum of expert and lay voices with varying degrees of agency, authority, and trustworthiness. ${ }^{75}$

In the midst of these complex interactions, the failure of regulatory agencies to prevent toxic risks has been noted in many studies, sometimes by expert insiders in a similar vein as van den Bosch. Evaggelos Vallianatos, who worked at the US Environmental Protection Agency's Office of Pesticide Programs, mentioned many examples from the 1980s and 1990s: conflicts of interest between regulators, industry-sponsored research along with large areas of undone science in epidemiology and toxicology of pesticides, politicians turned into de facto lobbyists for polluters, and even fake data produced by chemical laboratories under the control of industry. In spite of his gloomy portrayal, Vallianatos described many examples of successful control of pesticides, sometimes thanks to the heroic actions of experts and activists who joined forces in spite of the repressive measures taken against them in academic institutions or governmental agencies. ${ }^{76}$ Making connections between experts and activists seems a crucial issue not only in order to ensure the success of campaigns against toxic exposures but also to construct socially-robust knowledge on pest control. ${ }^{77}$

\footnotetext{
${ }^{74}$ See also May-Brith Ohman Nielsen, Små Paradiser. Hager gjennom et århundre (Oslo: Portal Akademisk, 2015).

${ }^{75}$ Harry Collins and Robert Evans, Rethinking Expertise (Chicago: University Press, 2007); Graeme Gooday, "Liars, Experts and Authorities," History of Science 46, no. 4 (2008): 431-56.

${ }^{76}$ E. G. Vallianatos and McKay Jenkins, Poison Spring: The Secret History of Pollution and the EPA (New York: Bloomsbury Press, 2014).

${ }_{77}$ Gwen Ottinger and Benjamin Cohen, eds., Technoscience and Environmental Justice: Expert Cultures in a Grassroots Movement (Cambridge, Mass: MIT Press, 2011).
} 


\section{Victims and activists}

Due to the fragmentation of the regulations and the inefficiency of the agencies, it is likely that many people were "legally poisoned" by pesticides. ${ }^{78}$ The social distribution of toxic risks is far from egalitarian. Minorities, the poor and the marginalized are the groups most likely to be the victims of toxic exposures, either as workers in sprayed farms, consumers of bad quality food, or residents of areas affected by the deterioration of environmental conditions. Gender discrimination, social inequalities, racist prejudices, and toxic injustice go hand in hand in different political and economic geographies along with different forms of imperialism and global military domination. According to a recent UN report, "pesticides are responsible for an estimated 200,000 acute poisoning deaths each year, 99 percent of which occur in developing countries." It is more difficult to offer reliable numbers on people affected by long-term pesticide exposure. Current estimates range in millions per year, mostly affecting impoverished areas. ${ }^{79}$

In spite of the failure of regulatory agencies and the unbalanced distribution of profits and costs, historical studies have rescued the voices of many groups that held out successfully against the "pesticide treadmill." The resistance included members of the expert communities (van den Bosch was an outstanding example), recalcitrant farmers (who opposed the imposition of modernization with agrochemicals), agricultural trade unions (concerned with accidents related to the use of pesticides), public health officials (like those who reported the poisoning accidents caused by lead arsenate in Bertomeu's paper), groups who suffered the ill-effects of pesticides (for instance their effect on the bee population, described in Frøyen's paper), as well as consumer associations, rural communities or environmental activists - each group with its own particular concerns, discourses, and forms of action. Activists and victims have also been able to devise new methods of data gathering and toxic evidence-making, which are aimed at enforcing reparative and transformative actions and alternative forms of justice. ${ }^{80}$

Recovering the disparate range of victims' voices is a challenge for historians. Access to government archives on these sensitive topics is not always easy to obtain, and it is even harder to describe the under-the-table activities of the pesticide industry, whose archives are only rarely made available to academic research (for instance, in cases in which judicial orders or

\footnotetext{
${ }^{78}$ Vallianatos, Poison Spring; Carl F. Cranor, Legally Poisoned: How the Law Puts Us at Risk from Toxicants (Cambridge, Mass: Harvard University Press, 2011).

${ }^{79}$ Report of the Special Rapporteur on the Right to Food (New York: UN, 2017). See the data offered by Pimentel and Lehman, The Pesticide Question, 47-49.

${ }^{80}$ Lyons, "Chemical Warfare in Colombia, Evidentiary Ecologies and Senti-Actuando Practices of Justice"; Phil Brown, Toxic Exposures: Contested Illnesses and the Environmental Health Movement (New York: Columbia University Press, 2007); Susanna Rankin Bohme, Toxic Injustice: A Transnational History of Exposure and Struggle (Oakland, California: University of California Press, 2015).
} 
historical activism are in motion). ${ }^{81}$ Moreover, the hazards caused by pesticides are usually imposed on marginalized groups, so we are unlikely to find their voices in government archives or other historical sources. Examples are the migrant farmworkers in northern Mexico, cotton workers in agribusiness in Central America, black farmers in the Mississippi Delta, Inuit women in Canada, Putumayo rural communities or the Norwegian and Spanish farmers and family gardeners described in the papers included in this volume. ${ }^{82}$ Many of these poisoned victims left behind no medical or historical records. In the case of farmworkers, for instance, epidemiological data are lacking due both to their mobility and to the inadequacy of medical programmes. The result is a structural under-reporting of chronic pesticide poisoning which paradoxically legitimizes the risk assessment procedures in place and blocks or delays regulatory changes. ${ }^{83}$

However, ethnographic analysis and oral history have proven to be excellent tools for recovering the victims' voices. In one of the most famous studies, Angus Wright reconstructed the silenced death of a mixteca farmworker, Ramón González, who passed away after being exposed to large doses of organophosphate pesticides. With the help of interviews and field research, Wright reviewed the broad array of issues that rendered the problem invisible: migrant populations of poor farmworkers, lack of concern/knowledge among occupational doctors, agriculture science programmes based on fake cost/benefits analysis, the macho culture of toxic hazard neglect, and the difficulties facing the different groups of victims farmworkers, rural communities, consumers, conservationists, etc. - in their attempts to launch joint action. The "modern agricultural dilemma" is rooted in the opposition between "the highly localized adaptations needed for ecological healthy agriculture and healthy, stable rural communities" and the "apparent requirements of rapidly industrializing nations and an expanding international economy." ${ }^{84}$

Wright claimed not just that new technologies create social conflicts in agriculture, but also that conflicts encourage the selective development of certain technologies, such as organophosphate pesticides. By assuring that there is no alternative to pesticide use, the technocratic approach

\footnotetext{
${ }^{81}$ Apart from the famous tobacco files, see the recent https://www.toxicdocs.org/ (accessed November 28, 2018). Other interesting joint projects rescuing silenced voices are the "Environmental Justice Atlas" (https://ejatlas.org, accessed February 28, 2019) and the "Toxic Bios project." See Marco Armiero et al., "Toxic Bios: Toxic Autobiographies—A Public Environmental Humanities Project," Environmental Justice 12, no. 1 (2019): 7-11.

${ }_{82}$ Murray, Cultivating Crisis; Bruce E. Johansen, “The Inuit's Struggle with Dioxins and Other Organic Pollutants," American Indian Quarterly 26, no. 3 (2002): 479-90; Angus Wright, The Death of Ramón González: The Modern Agricultural Dilemma, revised edition (Austin: University of Texas Press, 2005); Daniel, Toxic Drift, Kristina Marie Lyons, "Guerra química en Colombia, ecologías de la evidencia y senti-actuar prácticas de justicia," Universitas Humanistica 84 (2017): 203-34.

${ }^{83}$ Dedieu, Jouzel, and Prete, "Les bénéfices du doute."

${ }^{84}$ Wright, The Death of Ramón González, 245. See also pp. 304-305.
} 
renders invisible the social options available and accentuates the unfair distribution of costs and benefits. In other words, apparently sound agricultural science, along with forms of ignorance and uncertainty, are ways of concealing and maintaining the imbalance between economic profit and victims' health. Wright shows the difficulty of mobilizing farmworkers into a collective for political action able to link up with other political and social movements such as consumers interested in food quality, or conservationists. Among the difficulties are the disparate range of perceptions, concerns, and interests among these groups, which produce different forms of resistance and political action. ${ }^{85}$

\section{A Role for History}

This review has shown that pesticides are good examples for thinking about chemicals as both material and political entities. Like hybrid seeds or domesticated species, pesticides are sociotechnological products which arose out of particular social contexts, sometimes deeply embedded in political values and social conflicts. ${ }^{86}$ Thanks to agricultural experts or agribusiness managers, pesticides can travel in time and space with their affordances, constraints and risks, which are not always visible. Pesticides are also "unruly technologies": once released into agroecosystems, they are transgressive, disregarding boundaries, altering environments and entering bodies without permission, and behaving in unpredictable ways. ${ }^{87}$ Though sometimes difficult to detect, they are material objects with a burden of toxic hazards. Historians have faced many challenges when dealing with these sociomaterialities, moving away from either technological determinism or hylozoism. Historicizing and revisiting Beck's Risk Society, studies on pesticides have found compelling evidence of the correlation between poverty and risk in modern societies. Their elusive nature is reinforced by practices of undone science and public inaction, which provide ways for escaping regulations like the ones mentioned in this review and in the papers included in this volume. ${ }^{88}$

${ }^{85}$ Jean-Noël Jouzel and Giovanni Prete, "Mettre en mouvement les agriculteurs victimes des pesticides," Politix 111, no. 3 (2015): 175-96. On Spanish farmers see Josep Espluga Trenc, "La exposición laboral a pesticidas en la agricultura: un caso de aparente subestimación del riesgo," Sociología del trabajo 51 (2004): 33-60. On the benefices of oral history, see also Timothy Cooper and Anna Green, "The Torrey Canyon Disaster, Everyday Life, and the 'Greening' of Britain," Environmental History 22, no. 1 (2017): 101-26.

86 See for instance Tiago Saraiva, Fascist Pigs: Technoscientific Organisms and the History of Fascism (Cambridge, MA: MIT Press, 2016).

${ }^{87}$ Jody A. Roberts, "Unruly Technologies and Fractured Oversight: Toward a Model for Chemical Control for the Twenty-First Century," in Powerless Science? Science and Politics in a Toxic World, eds. Soraya Boudia and Nathalie F. Jas, 254-68 (New York: Berghahn Books, 2014).

88 Soraya Boudia, Angela N.H. Creager, Scott Frickel, Emmanuel Henry, Nathalie F. Jas, Carsten Reinhardt, and Jody A. Roberts, "Residues: Rethinking Chemical Environments," Engaging Science, Technology, and Society 4 (2018): 165-78. 
The review also confirms that, like other studies on toxic products, historians of pesticides have enlarged the range of protagonists and now include experts, decision-makers, activists, judges, industry managers, victims, and the pesticides themselves. They have explored the blurred and contested borders connecting science, medicine, economic interests and politics when portraying the spectrum of epistemological (and agnotological) practices connecting (or disconnecting) toxic exposures and health hazards. Using a range of sources and hard-to-access documents, they have shown the interplay between corporate strategies, agronomic research and state policies. While most of the studies have been confined to particular contexts, collaborative projects have flourished in recent years, thus encouraging comparative perspectives and occasional attempts to produce a global history of toxic hazards in different societies and historical moments. Avoiding simple conspiracy theories, historians have also analysed in sophisticated ways the interactions between discursive constructions, sociotechnological objects, expert knowledge, vested interests, activism and decision-making. And yet, the powerful narrative of van den Bosch serves to recall that pesticides are embedded in social conflicts marked by the striking asymmetries regarding epistemic tools, political power, economic resources and access to mass media. ${ }^{89}$

Thomas R. Dunlap concluded his study on DDT in the United States remarking that "for this kind of problems there is no scientific answer." When talking about pesticides, political choices are at stake. In public debates, the most powerful groups can easily disregard the awkward conclusions of expert reports or, alternatively, silence the victims' voices by mobilizing the epistemological virtues of science. The studies reviewed suggest that history can be a powerful tool for rebalancing public debates on pesticides, while introducing fresh perspectives. Two difficulties seem to reduce the value of a historical analysis. First, the lack of master narratives competing with activist discourses and industry propaganda is a serious challenge to the attempts to turn fine-grained academic studies into food for thought in public arenas. Second, the literature on pesticides is affected by the evil of disaggregation, recalling, in a way, the fragmentation of the regulatory systems that limits the control on toxic products at national and international levels. Papers and books are published in a broad range of journals by authors from different academic disciplines. Following pesticides in different societies offers an opportunity to construct bridges between science studies and history of agriculture, while reinforcing the connection with studies on the history of public and occupational health

\footnotetext{
${ }^{89}$ For recent reviews of the literature, see José Ramón Bertomeu-Sánchez and Ximo Guillem-Llobat, "Following poisons in society and culture (1800-2000): a review of current literature," Actes d'història de la ciència i de la tècnica 9 (2017): 9-36; Claas Kirchhelle, "Toxic Tales-Recent Histories of Pollution, Poisoning, and Pesticides (ca. 1800-2010)," NTM Zeitschrift für Geschichte der Wissenschaften, Technik und Medizin 26, no. 2 (2018): 213-29.

${ }^{90}$ Dunlap, DDT, 245.
} 
and environmental history. ${ }^{91}$ By linking research projects, crossing disciplinary barriers and entering the public arena, historians are likely to play an important role in the uncertain future of pesticides. The four papers included in this volume are good examples.

${ }^{91}$ Deborah Fitzgerald et al., "Roundtable: Agricultural History and the History of Science," Agricultural History 92, no. 4 (2018): 569-604. We have developed these ideas in Bertomeu-Sánchez and GuillemLlobat, "Following poisons in society and culture (1800-2000)." 